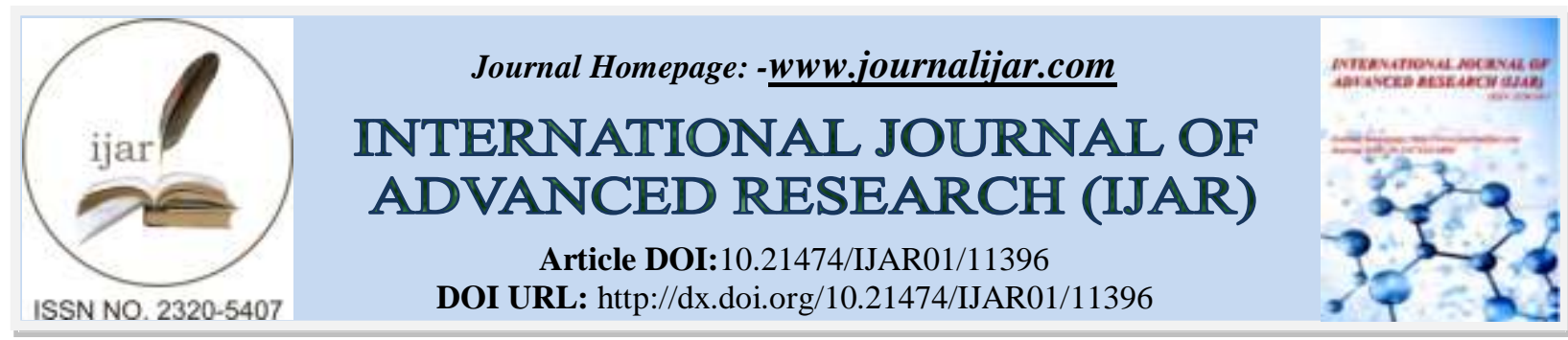

RESEARCH ARTICLE

\title{
RECONSTRUCTION OF LAW PROTECTION FOR WITNESS AND VICTIM'S RESTITUTION AND COMPENSATION BASED ON JUSTICE VALUE
}

\author{
Bambang Tri Bawono ${ }^{1}$, Halomoan Freddy Sitinjak Alexandra ${ }^{2}$, Gunarto $^{1}$ and Maidin Gultom ${ }^{3}$ \\ 1. Faculty of Law Sultan Agung Islamic University Semarang, Indonesia. \\ 2. Doctorate Student of Faculty of Law Sultan Agung Islamic University Semarang, Indonesia. \\ 3. Faculty of Law Santo Thomas Catholic University Medan, Indonesia.
}

\section{Manuscript Info}

Manuscript History

Received: 25 May 2020

Final Accepted: 28 June 2020

Published: July 2020

\section{Key words:-}

Reconstruction, Witness and Victim,Restitution and Compensation, Justice Value

\section{Abstract}

The tendency of the weak regulation of legal substance regarding the protection of victims and Witness of crime in terms of compensation and restitution so that guarantees of justice for victims of crime in general can not be felt by the majority of people in Indonesia. This is further worsened by the existing legal institutions that does not provide maximum guarantees for victims to obtain compensation. Therefore, according to the author, this issue is very interesting to study further where the main issue discussed are the weaknesses of the fulfillment of the right to restitution and compensation for victims and witness of criminal acts based on Witness and Victim Protection Law (UUPSK) in Indonesia and how is the form of reconstruction of the UUPSK based on justice. The study was conducted in the perspective of the Constructivism paradigm with the type of socio-legal research and qualitative approach methods. Data used in this research are from interviews and questionnaires supported by literature, legislation and various public documents, while the data analysis was carried out by the method of qualitative critical analysis. The results showed that the fulfillment of victims' restitution was constrained because in general the perpetrators were classified as being unable. Likewise with compensation, with guarantees in the law although limited to certain victims of crime, the state's readiness for this has not been maximized as evidenced by the management of the APBN funds in the Ministry of Finance; no allocation of funds has been prepared for compensation payments. Likewise, the agency that submitted a budget request by making a Work Activity Funding Draft never submitted a request for compensation payment post for a crime victim. This fact shows that the government is not consistent with what is promised in the law to victims of criminal acts regarding the right to compensation. Furthermore, regulation of material criminal law, formal criminal law and the law on the implementation of criminal restitution (strengthening the force of restitution). Guarantees of the right to restitution and compensation must be given to all victims of criminal acts, with an easy and effective mechanism and requires the participation of law enforcement officials namely investigators, public 
prosecutors and judges to provide justice for victims of crime so a strengthening of the Witness and Victim Protection Agency is needed. as a non-departmental institution that has a strong position to work in the criminal justice system for the benefit of victims of criminal acts in fulfilling the right to restitution and compensation based on justice therefore the Strengthening as intended is the reconstruction of law number 31 of 2014 concerning witness and victim protection is needed.

Copy Right, IJAR, 2020,. All rights reserved.

\section{Introduction:-}

One of the rights of Indonesian citizens guaranteed in the 1945 Constitution is the right to protection of personal, family, honor, dignity and property through its legal instruments. And if a crime occurs that causes Physical harm to the victim then the state is deemed to have failed to fulfill its obligations to protect its citizens. Therefore morally the State must assume the responsibility of providing compensation to victims of criminal acts.

This Compensation should also get attention, especially to victims of conventional crime, such as murder, rape, torture, victims of robbery and rape, as they got not much attention from mass media. The Fact in the community shows that many victims of crime did not receive compensation for the crimes they experienced and even if they obtained them as an effort taken through non-litigation in the form of mediation with the perpetrators of the crime in the hope for the perpetrators that the case would not be prosecuted. This opens our eyes that whenever there is a crime the working of the criminal law is only oriented towards proving the crime, while the issue of compensation becomes a personal matter that must be fought by the victim him or herself. Although the criminal law has provided a pathway for the Compensation of Lawsuit for Compensation in Article 98 of the Criminal Procedure Code, the provisions have not been maximized in its regulation and application, with consideration that the requirements for examining a case merger must be requested by the victim him or herself.

One of the previous researches (waluyan;2020) shows that in the Semarang City jurisdiction, there has not been a victim of a criminal offense who filed a request to combine a claim for compensation for the perpetrator based on Article 98 of the Criminal Procedure Code. The ineffectiveness of the provisions of this article is partly because the victim of a criminal offense as a layman is not aware of the existence of such rights and does not know the legal procedures. On the other hand law enforcement officers (investigators) in this case assume that the investigator does not have the authority to convey to the victim about the merger efforts that exist in the Criminal Procedure Code and fully become the authority of victims of crime.

Another empirical reality was explained by Eva Achjani Zulfa (2009) in her research that in the jurisdictions of Jakarta, Bogor and Tangerang in general, alternative solutions to the resolution of criminal cases outside the judicial process would be the people's choice. This conclusion was obtained from the analysis of the opinions of 250 respondents who had been involved as perpetrators and victims, with a composition of $62 \%$ of respondents in cases of murder, ill-treatment, rape, theft, choosing not to be forwarded to the prosecution level (stopping at the police level) and $82 \%$ of the case of traffic accident solved thru peaceful efforts as a solution. This fact shows that the public has not yet gained full trust in the criminal justice system that has been working so far, which seems to have paid less attention to victims of criminal acts. The government should make a policy of criminal law enforcement that also takes into account the interests of victims of crime through both criminal and non-criminal channels. Because ideally not all types of crime can be resolved peacefully by stopping the prosecution.

Based on the phenomena mentioned above, the issue of this study is that there is a tendency for the weak regulation of legal substance regarding the protection of victims of criminal acts in terms of compensation and restitution so that guarantees of justice for victims of crime in general can not be felt as a whole. And the existing legal institutions have not provided maximum guarantees for victims to get compensation. Therefore, according to the author, this problem is very interesting to study further with the following main issues :

1. What are the weaknesses of the UUPSK's Regulation in fulfilling the right to restitution and compensation for victims of criminal acts in Indonesia?

2. How is the reconstruction of UUPSK in providing restitution and compensation for victims of criminal acts in Indonesia based on the value of justice? 
The paradigm that is used in the research this is the paradigm of Constructivism which is the antithesis of the understanding that lay observation and objectivity in finding a reality or science knowledge (faisal;2010). Paradigm also looked at the science of social as an analysis of systematic against Socially Meaningful Action through observation directly and in detail to the problem analyzed.

The research type used in writing this paper is a qualitative research. Writing aims to provide a description of a society or a certain group of people or a description of a symptom or between two or more symptoms.

Approach ( approach) the research is to use the approach of Socio-Legal, which is based on the norms of law and the theory of the existing legal enforceability of a law viewpoint as interpretation (johnny;2005).

In this study, researchers uses data collection techniques, namely interview and questionnaire supported with literature study, interviews and documentation. In this study, the researcher is a key instrument that is the researcher himself who plans, collects, and interprets the data (moleong;2002).

\section{Discussion:-}

Weaknesses Of The UUPSK's Regulation In Fulfilling The Right To Restitution And Compensation For Victims Of Criminal Acts In Indonesia:

The model of regulating the fulfillment of victims 'rights to restitution and compensation in legislation generally requires victims' initiative to work through applications to the court. This model seems to still recognize the sharp separation between criminal law and civil law, between public law and private law, so this classic view still seems to influence the regulation of the legal provisions of victims' protection against the struggle for compensation. Legal arrangements for victim protection like this are very unfavorable for victims of crime, given the condition of the community of victims of criminal acts, in general people who are laymen in the system of law do not know the rights and mechanisms of claims for restitution and compensation. As a result, this model seems to place victims as victims of the existing system. Based on the data obtained by the author from the ministry of law and human rights in 2019 shows the reality of the condition of victims of crime who generally do not know of the guaranteed right to restitution and its mechanism is proven by only $0.83 \%$ (1 of 120 victims) who know of the existence of restitution and mechanism rights, the rest $99.17 \%$ the victim did not know the guarantee of rights and mechanisms.

Other subjective conditions that also influence victims' recovery efforts are the average perpetrators of criminal offenses classified as underprivileged people (69.17\%) so that many of the victims of criminal acts are resigned to the situation and finally just leave the matter to the authorities in the hope of the victim obtain justice through a judge's decision.

In addition, in general the perpetrators of crime are willing to provide compensation provided to the victim that does not report or revoke the report in the police, even though it is not as easy as it can be done against serious crimes and is public offense. In criminal law, crimes that are classified as offense complaints that can be hung on the complaint or withdraw the complaint. And legal certainty requires investigators not to do anything that is contrary to law and law enforcement because basically the policy of the police in determining the attitude in handling cases of one of the grounds should not be contrary to law.

Another empirical proof by the autor based from an Interview with the Head of Legal Aid at the Ministry of Finance of the Republic of Indonesia, Mr. Didik Suswandi, S.H. in Jakarta on 10 September 2018. is that there are victims who take advantage of the position of the perpetrators of crime by acting as if blackmailing the perpetrators by asking for compensation money that is too large beyond his ability. A case of mistreatment of a victim of a woman who only suffered a bruise that was not too severe through mediation with the perpetrators outside the court demanding compensation money of Rp. 30,000,000 to the perpetrators. Actors in this case felt the victim's request was too excessive and finally the mediation effort found a dead end. To avoid the negative impacts that might arise in the mediation process each party requires good faith. In the mediation process the role of the mediator becomes a very determining factor in the success of mediation. This function should be carried out by parties who have no interest in handling cases such as the police, prosecutors and judges so that the objectivity of the case can be maintained.

Finance is a very fundamental issue in the legal issues of protection of victims of crime in terms of restitution and compensation because it concerns the ability and good faith of the perpetrators to pay and the ability of the state to 
fulfill them when restitution is not obtained from the perpetrators of the crime. Implementation of restitution and compensation is not without obstacles in its execution so that the suffering of victims of physical injury and loss of property is borne by themselves without any attention from the perpetrators and the state. In some cases theft and embezzlement are most fortunate if the goods which are the object of crime are still present and subject to confiscation and can ultimately be returned to the victim through a judge's decision. But in general the objects of the crime are no longer in the hands of the perpetrators and mediation efforts cannot be carried out because the perpetrators are classified as unable to financially.

The results of research conducted by the author from the ministry of law and human rights in 2019shows that the frequency with which perpetrators generally occur in Indonesia comes from disadvantaged groups (69.17\%) because they do not have jobs (27.50\%), have jobs (laborers, artisans, farmers, drivers) but income is not sufficient for daily living needs (41.67\%) so the perpetrators are forced to commit property crimes. The harshness of life and competition of life makes communication and social relations of the community vulnerable to conflicts of interest and ultimately triggering violence and other crimes.

Furthermore, the obstacles to fulfillment of restitution and victim compensation are generally divided in to (lukman;2020) :

1.The financial condition and economic capability of the offender which is classified as not able.

2.Perpetrators are classified as financially capable but there is no good faith to provide restitution to victims because the perpetrators assume that the imprisonment that has been imposed to him or her as a punishment to commensurate with the victim's suffering and at least provides inner satisfaction to the victim, so that compensation is no longer needed as seen in the perceptions of respondent of perpetrators of crime Data against this that has reached $83.3 \%$ (100 respondents from 120 respondents perpetrators)

3.The state's financial condition will not be able to meet the transfer of the perpetrators' responsibility to pay compensation to all victims of crime. Therefore a concept is needed to strengthen the execution power of restitution. But even so, as a last step as a form of state responsibility, it requires a realistic model that can be empowered and effective for the purpose of victim recovery and at the same time the purpose of the criminal justice system.

Regardless of the condition and state finances, the most important thing is that the government must have the will and good faith to provide attention and justice for victims of crime through the policy of improving the institutional reform law by providing sufficient bailout funds. Government consistency is needed in this matter between what has been guaranteed and promised as victims' rights (compensation) in the law with the support of financial facilities that must be harmonized with the APBN.

This fact shows that the government is not consistent with what is promised in the law to victims of crime regarding the right to compensation because it is clearly stated in Article 3 of Government Regulation No. 3 of 2002 that the relevant Government Agencies (including the finance department) are tasked with carrying out compensation based on decisions of Human rights court which has obtained permanent legal force. In the case of compensation concerning the financing and calculation of state finances, the implementation shall be carried out by the Ministry of Finance.

\footnotetext{
Reconstruction Of UUPSK In Providing Restitution And Compensation For Victims Of Criminal Acts In Indonesia Based On The Value Of Justice:

Criminal law enforcement (An enforcement of law by strengthening the force of execution of restitution) is a policy that needs to be considered and acted upon considering that in the existing legislation there is a legal vacuum in which the regulation does not seek to the maximum the possibility of the implementation of restitution execution and does not necessarily immediately turn to substitute imprisonment as regulated in Article 99 paragraph (2) of the 2019 Penal Code Draft if the offender is unable to pay. This needs to be done because in reality some perpetrators of crimes are not unable but do not want to pay for the restitution because they believe the payment of restitution does not abolish the main Penalty, i.e; imprisonment that he or she must serve. Furthermore, the strengthening of the restitution execution is intended to avoid the possibility of an easy shift of responsibility for restitution which is the responsibility of the perpetrators to state responsibility in the form of compensation, so that the state is not burdened by the State Budget for bailout funds in the context of the concept of subrogation.
}

The regulations for strengthening the execution power that can be done are as follows: 
a. Efforts to seize collateral (conservatoir beslag) at the stage of the investigation of the assets of the perpetrators of crime as a reinforcement or maximum effort to be able to realize the fulfillment of the restitution of victims obtained through a judge's decision. This step is important to do to fill the legal vacuum in strengthening the execution power to avoid as early as possible the imposition of substitute imprisonment criminal subsidiary if restitution is declared unable to be paid by the offender.

\section{Civil liability substitutes based on Article 1367 of the Civil Code which confirms that:}

1. A person is not only responsible for the loss caused by his own actions, but also for the loss caused by the actions of those who are under his or her guardianship or due to the goods that are under his or her supervision.

2. Parents and guardians are responsible for losses caused by minors who live under them and for whom they exercise the authority of their parents or guardians.

3. Employers and people who appoint others to represent their affairs, are responsible for losses caused by their servants or subordinates in carrying out the work assigned to these people.

4. The school teacher or the master craftsman is responsible for the losses caused by his students or their craftsmen during the time the people are under his supervision.

This provision can be used as a basis for maximizing the fulfillment of the right to restitution if the perpetrators of crimes are classified as those in the possession and responsibility of parents / guardians, employers, teachers, head masons who cannot fulfill their obligations to pay restitution. The responsibility of the child offender who is burdened with the obligation to pay compensation to the victim, this responsibility can be transferred to the parent / guardian altough it is very unfortunate that in Law Number 11 of 2012 concerning the Criminal Justice System for Children, additional criminal sanctions for compensation payments have been abolished, even though the solution to the execution can be applied under Article 1367 of the Civil Code, namely civil liability for civil servants, given that criminal penalties for compensation payments are a function of restoration and not an entrapment function.

Payment by the heirs are mutually agreed between parents and children, husband and wife as perpetrators to victims of criminal offenses if the offender has been convicted and then dies. This construction is based on Article 1826 of the Civil Code which confirms that: "The agreements of the guarantor are transferred to their heirs."

Payment in installments are on the basis of an agreement between the perpetrators and victims of criminal acts.

Payment is jointly liable in the case of deelneming (inclusion).

Forced power as mentioned above can be followed up with a consignment, in addition to the possibility of an auction of the assets of the perpetrators to fulfill their responsibilities that are likely to be dropped in the judge's decision. Consignment means safekeeping of money or goods in court for payment of a debt. The consignment begins with an offer of payment followed by a deposit in court (Articles 1404-1412 of the Civil Code). This construction is used to maximize the payment of restitution for victims of trafficking in persons as regulated in Article 48 (5) of Law Number 21 Year 2007 concerning Eradication of Trafficking in Persons that restriction as referred to in paragraph (4) can be deposited first in the court where the case is decided. The benefits of consignment are to obtain certainty in fulfilling the right to restitution and to maintain and guarantee the authority of judges who have implemented criminal offenses as a result of good faith in the form of offers for payment of restitution by criminal offenders.

The law is basically a system that works to realize its objectives. The system has two meanings that are important to recognize. First, the system as a type of unit, which has a certain order, the order in this case shows a structure composed of parts. Second, the system as a plan, method or procedure for doing something. In general the system is goal-oriented, the system is composed of several parts, and the parts work in an integrated manner. The parts in the system are arranged based on the objectives to be achieved. Likewise with criminal justice system, the operation of the system is always oriented to the interests of the law protected by law and the legal objectives to be achieved.

\section{The purpose of the criminal justice system that works so far are to :}

1. Prevent the People from becoming victims.

2. Resolving cases of crimes that occur so that the community is satisfied that justice has been upheld and the guilty convicted

3. Make sure that those who have committed a crime do not repeat the crime again. 
The model built so far in the criminal justice system on the basis of criminal law acts (daadstrafrecht) which is based on the perpetrators of crime is time to be abandoned. According to Muladi (2012), the realistic model is what that takes into account of various interests that must be protected by criminal law, namely the interests of the state, public interests, individual interests, interests of perpetrators and victims of crime. The model which relies on the daad-daderstrafrecht concept by Muladi is called the Interest-Balance Model. If this is the case with understanding the law and what is the purpose of the law, the criminal justice system should work to create justice for the interests of victims of crime. For this reason, the criminal justice system requires the role of Penal institutions to work to help judges find material truth in order to create justice while fighting for the interests of victims of crime in the criminal justice system.

With reference to the Services Model (vitasari;2020) that appears in Indonesian legislation, the role of institutions whose functions and authority are oriented to the interests of victims of crime is very necessary given the service model's position of victims is not as a subjects who have rights In the broad juridical rights. In the Model of procedural rights, the emphasis is to allow victims to play an active role in the proceedings of the judicial process. For example the victim is given the right to make criminal charges or help the prosecutor, the victim is asked for his opinion by the prison before being given a conditional release and so on.

Whereas in the victim service model is passive and is a party that needs to get services and facilities for its interests in the criminal justice system. The essential application of the service model really requires the role and authority of an institution that works and is oriented to the interests of victims of criminal acts. Victims in the criminal justice system as parties that need to be protected and concerned about their interests, the service model requires standard standards for law enforcement (police, prosecutors, judges) in the form of Integrated Service Standardization guidelines for victims of criminal acts. Particularly with regard to restitution and standard compensation standards for law enforcement officers is very important considering the criminal justice paradigm has long dominated the thinking and pattern of handling criminal cases by law enforcement officials without regard to victims of criminal acts. The service model standardization model at the level of investigation and prosecution requires investigators and public prosecutors to position victims as subjects who need to be provided with services such as the provisions contained in the Human Trafficking Law (TPPO law) which according to the author are the only aspirational laws which provides services and attention to TPPO victims as a reflection of the services model.

Victims of trafficking in persons according to the provisions of Article 48 paragraph 1 of Law Number 21 Year 2007 assert that "the mechanism for filing a restitution is carried out since the victim reports her case to the local police and is handled by the investigator together with the handling of the criminal act committed. The public prosecutor informs the victim of his right to apply for restitution, then the public prosecutor submits the amount of loss suffered by the victim due to the crime of trafficking in person together with the charges ".

In this mechanism, the victim can directly submit a request for restitution to the investigator and be dealt with in conjunction with the handling of the criminal act, subsequently included in the prosecution's demands.

In law enforcement practices at the investigation level, in the case file (especially in the victim and witness case report/ BAP) the investigator has included restitution material. Inclusion of the amount of restitution demanded by the victim in the BAP has not yet been detailed, as well as the evidence that can be submitted as a basis for obtaining restitution. In some cases, investigators have collaborated with Witness and Victim Protection Foundation (LPSK) regarding the calculation of the cost of restitution (komariah;2015).

In addition, related to TPPO victims, in the Technical Guide for Submission of Restitution based on JAMPIDUM Letter No. 3718 / E / EJP / 11/2012 dated November 28, 2012 Regarding Restitution in the Case of the Criminal Act of Trafficking in People:

"... the handling of cases of trafficking in person where the victim has not filed a restitution at the investigation stage to : a. In order for the public prosecutor to notify the victim of his right to apply for restitution in the form of compensation for loss of wealth or income, suffering, costs for medical care, other losses suffered by the victim due to trafficking in persons and; b. In criminal charges, the public prosecutor conveys the total amount of loss suffered by victims due to trafficking in persons ". 
In the pre-prosecution stage, the Prosecutors researcher related to the TPPO case dossier which did not include restitution had given instructions so that the restitution was used as a substance of the examination, both the examination of the victim's witnesses and the suspect. Ask the investigator to mediate (not in the context of stopping the handling of criminal cases), but to seek an agreement on the amount of restitution requested by the victim with the ability of the suspect to pay restitution. Furthermore, at the prosecution stage, if an investigation is not reached at an investigation level, progressively the public prosecutor when submitting Phase II documents will again try to mediate the restitution requested by the victim with the ability of the suspect / defendant.

The aforementioned mechanism clearly requires the dual role of the investigative apparatus and the public prosecutor to take care of the interests of the victim in addition to the main task in solving the criminal case. For this reason, it is necessary to have standard standards that guide law enforcement officers and in handling TPPO cases the standard standards mentioned above can be developed and used as guidelines in making general standards in handling criminal cases in general, standard standards that become general guidelines in handling cases of victims of criminal acts so that get justice-based restitution and compensation regulated in the witness and victim protection law, for this reason, a reconstruction of law number 31 of 2014 concerning witness and victim protection is urgently needed. By reconstructing the witness and victim protection law, the Witness and Victim Protection Agency will be stronger because it has broader and greater authority, duties and obligations.

Likewise, the service model for judges can be in the form of active participation of judges to reveal the facts of victims' suffering in addition to criminal acts of perpetrators, which in the end can be in the form of restitution or compensation as a service model that provides restorative justice.

\section{Conclusion:-}

The fulfillment of victims' restitution is constrained because in general the perpetrators are often classified as unable. Likewise with compensation, with guarantees in the law although limited to certain victims of crime, the state's readiness for this has not been maximized yet as evidenced by the management of the APBN funds in the Ministry of Finance; no allocation of funds has been prepared for compensation payments. Likewise, the agency that submitted a budget request by making a Work Activity Funding Draft never submitted a request for compensation payment post for a crime victim. This fact shows that the government is not consistent with what is promised in the law to victims of criminal acts regarding the right to compensation

Material criminal law regulation, formal criminal law and the law of implementing criminal restitution (strengthening the force of restitution) and Guarantees of the right to restitution and compensation must be given to all victims of criminal acts, with an easy and effective mechanism and requires the participation of law enforcement officials namely investigators, public prosecutors and judges to provide justice for victims of crime so a strengthening of the Witness and Victim Protection Agency is needed. as a non-departmental institution that has a strong position to work in the criminal justice system for the benefit of victims of criminal acts in fulfilling the right to restitution and compensation based on justice. The Strengthening as mentioned above is the reconstruction of law number 31 of 2014 concerning witness and victim protection.

\section{The Writer's brief biography:}

Bambang Tri Bawono is a Lecturer of Law Faculty at Sultan Agung Islamic University (UNISSULA), Semarang, Indonesia. Jl. Raya Kaligawe KM 4 Semarang, Central Java, Indonesia.

\section{References:-}

Books:

1. Eva Achjani Zulfa.,2009, Dissertation, Keadilan Restoratif di Indonesia (Study tentang Kemungkinan Penerapan Pendekatan Keadilan Restoratif dalam Praktek Penegakan Hukum Pidana), Faculty of Law Universitas Indonesia.

2. Faisal.,2010, “Menerobos Positivisme Hukum”, Rangkang Education, Yogyakarta.

3. Interview with the Head of Legal Aid at the Ministry of Finance of the Republic of Indonesia, Mr. Didik Suswandi, S.H. in Jakarta on 10 September 2018.

4. Johnny Ibrahim.,2005, “Teori dan Metodologi Penelitian Hukum Normatif”, Bayumedia, Surabaya.

5. L. Moleong.,2002, "Metode Penelitian Kualitatif”, PT Remaja Rosdakarya, Bandung. Journal 
6. Hakim, Lukman.,2020. Analisis Ketidak Efektifan Prosedur Penyelesaian Hak Restitusi Bagi Korban Tindak Pidana Perdagangan Manusia (Trafficking).Jurnal Kajian Ilmiah. 20. 43-58. 10.31599/jki.v20i1.69.

7. Komariah, Mamay.,2015. PERLINDUNGAN HUKUM SAKSI DAN KORBAN OLEH LEMBAGA PERLINDUNGAN SAKSI DAN KORBAN (LPSK). Jurnal Ilmiah Galuh Justisi. 3. 229. 10.25157 /jigj.v3i2.421.

8. Siku, Abdul \& Muhadar, Mr \& Karim, M.,2012,The Protection of Human Rights of the Witness and Victim during Criminal Proceeding. Journal of Sociological Research. 3. 10.5296/jsr.v3i2.2917.

9. Vitasari, Salsabila \& Sukananda, Satria \& Wijaya, Sandra.,2020,Pelaksanaan Pemberian Restitusi Terhadap Korban Tindak Pidana Perdagangan Orang.DIVERSI : Jurnal Hukum. 6. 92. 10.32503/diversi.v6i1.998.

10. Waluyan, Vrimadieska \& Suharso.,2020,KECEMASAN NARAPIDANA KASUS PEMBUNUHAN PADA LEMBAGA PEMASYARAKATAN KELAS I SEMARANG. Indonesian Journal of Counseling \& Development. 2. 1-17. 10.32939/ijocad.v2i01.12. 